NBER WORKING PAPER SERIES

\title{
SEGREGATION AND BLACK POLITICAL EFFICACY
}

\author{
Elizabeth Oltmans Ananat \\ Ebonya L. Washington \\ Working Paper 13606 \\ http://www.nber.org/papers/w13606
}

\section{NATIONAL BUREAU OF ECONOMIC RESEARCH \\ 1050 Massachusetts Avenue \\ Cambridge, MA 02138}

November 2007

We are grateful to Michael Anderson, Charles Clotfelter, Philip Cook, Jonathan Gruber, Joanna Lahey, Jacob Vigdor and to seminar participants at University of Connecticut, George Mason University, NBER Political Economy fall 2007 meeting, New York University, Ohio State University, Stanford University, University of Wisconsin and Washington University for helpful comments. We thank Meredith Levine for research assistance. The views expressed herein are those of the author(s) and do not necessarily reflect the views of the National Bureau of Economic Research.

(C) 2007 by Elizabeth Oltmans Ananat and Ebonya L. Washington. All rights reserved. Short sections of text, not to exceed two paragraphs, may be quoted without explicit permission provided that full credit, including $(\mathrm{C}$ notice, is given to the source. 
Segregation and Black Political Efficacy

Elizabeth Oltmans Ananat and Ebonya L. Washington

NBER Working Paper No. 13606

November 2007, Revised February 2008

JEL No. D72,J15

\begin{abstract}
$\underline{\text { ABSTRACT }}$
The impact of segregation on Black political efficacy is theoretically ambiguous. On one hand, increased contact among Blacks in more segregated areas may mean that Blacks are better able to coordinate political behavior. On the other hand, lesser contact with non-Blacks may mean that Blacks have less political influence over voters of other races. As for non-Blacks, inter-group conflict theory suggests that greater contact yields greater conflict between the groups while inter-group contact theory suggests exactly the reverse. We investigate this question empirically. We find that exogenous increases in segregation lead to decreases in Black civic efficacy, as measured by an ability to elect Representatives who vote liberally and more specifically in favor of legislation that is favored by Blacks. This tendency for Representatives from more segregated MSAs to vote more conservatively arises in spite of the fact that Blacks in more segregated areas hold more liberal political views than do Blacks in less segregated locales. We find evidence that this decrease in efficacy is driven by more conservative attitudes amongst non-Blacks in more segregated areas.
\end{abstract}

Elizabeth Oltmans Ananat

Sanford Institute of Public Policy

Duke University

Box 90245

Durham, NC 27708

and NBER

eoananat@duke.edu

Ebonya L. Washington

Yale University

Box 8264

37 Hillhouse, Room 2

New Haven, CT 06520

and NBER

ebonya.washington@yale.edu 
"The power of the ballot we need in sheer defense, else what shall save us from a second slavery?”

--W.E.B. DuBois

"The vote is the most powerful instrument ever devised by man for breaking down injustice and destroying the terrible walls which imprison men because they are different from other men.”

--Lyndon B. Johnson

\section{Introduction}

A large literature suggests that segregation is associated with more negative outcomes for Blacks. ${ }^{1}$ Blacks in more segregated areas are found to have higher infant mortality, lower educational attainment, and fare worse on a host of other outcomes than Blacks in less segregated areas. Ananat (2007) shows that even when the endogeneity of segregation is carefully controlled for, Blacks in more segregated cities have lower education, employment and earnings than their counterparts in less segregated cities.

In this paper we explore the impact of segregation on a previously unexamined outcome: politics. Although the relationship between political outcomes and area racial and ethnic heterogeneity has been extensively studied, ${ }^{2}$ this is the first paper, to our knowledge, to examine the relationship between segregation and Black civic efficacy. We define Black political efficacy ${ }^{3}$ as the ability to elect Representatives who vote (in Congress) in a manner that the Black electorate favors. Under this definition, it is clear that the political views and actions of both Black and non-Black citizens will affect efficacy. In fact, given that in no MSA are Blacks a majority of the population, the behavior of non-Blacks may be more important than the behavior of Blacks in determining Black political efficacy. A priori, the relationship between segregation and

\footnotetext{
${ }^{1}$ See for example Massey and Denton (1995).

${ }^{2}$ This literature concludes that both political participation and public goods expenditures are decreasing in racial heterogeneity. See Costa and Kahn (2003) for a summary.

${ }^{3}$ We use the terms "political efficacy" and "civic efficacy" interchangeably.
} 
Black civic efficacy is ambiguous. On the one hand, the more segregated Blacks are the more contact they have with other Blacks and thus the more likely they are to be able to influence Black political behavior. On the other hand, the less segregated Blacks are the more contact they have with non-Blacks and the more likely they are to be able to influence non-Black political behavior. As for non-Blacks’ propensity to align themselves politically with Blacks, inter-group conflict theory suggests that greater contact yields greater conflict between the groups while inter-group contact theory suggests exactly the reverse. (See for example Taylor 1998 and Bobo 1988 on inter-group conflict theory and Johnson et. al 2000, 2001 on inter-group contact theory).

We bring empirical evidence to bear on this theoretical ambiguity. Clearly the challenge to an empirical analysis of the impact of segregation on any outcome is the endogeneity of segregation. (For example, perhaps non-Black residents' preference for interactions with Blacks influences both the level of segregation and the level of Black efficacy.) We circumvent this difficulty by using the railroad division index developed in Ananat (2007) to instrument for segregation. Before the Great Migration--the large movement of Blacks from the South to the North during the years 1915 to $1950^{4}$--Blacks predominantly lived in former slave-holding states. The instrument exploits the fact that this Great Migration occurred after the vast majority of the country's present day railroad tracks had been laid. The more subdivisions created in a city by the tracks (conditional on the total amount of track in the city), the easier it was in that city to confine (segregate) Blacks in neighborhoods whose boundaries were defined by these tracks. (One limitation of this identification strategy is that we can only explore the impact of segregation on civic efficacy outside of the South.)

\footnotetext{
${ }^{4}$ Some historians put the end date of the Great Migration at as late as 1970.
} 
Employing the railroad instrument, we find that in the non-South, segregation, conditional on area racial heterogeneity, has a negative causal impact on Black civic efficacy. The more segregated the metro area, the less likely that its residents are represented in the United States House by a Black representative or by an individual of either race who is from the Democratic Party ${ }^{5}$ or who votes in accordance with the desires of Black residents on civil rights and other issues. Although the relationship between segregation and our various measures of efficacy is not always significant, it is remarkably consistent. The negative relationship has held from the first redistricting period after the Voting Rights Act through the most recently completed redistricting period (or from 1973-2002). Given evidence that the tendency for Blacks to align themselves towards the left in the political continuum is increasing in segregation, our findings demonstrate that Black civic efficacy is decreasing in segregation.

What is the channel by which segregation impacts Black civic efficacy? We find no evidence that variation in district demographic configuration drives our results. We also rule out variation in voter turnout by race as a possible explanation. We do, however, find evidence that in more segregated areas non-Blacks are more likely to hold negative views of Blacks and of policies that aid Blacks. Further, we find some support for the argument that segregation increases divergence between Black and non-Black political views. Because Blacks are a minority of the population in all metro areas, this polarization could explain the finding that Black civic efficacy is decreasing in segregation.

As exemplified by the quotations with which we began, there is a deep-seated belief in this country in the ability to effect change by pulling a lever on Election Day.

\footnotetext{
${ }^{5}$ Blacks vote Democratic 70 to 90\% of the time in two-party elections (McDermott 1998).
} 
Such a belief implies that Black political efficacy may be a mediator in the relationship between segregation and Black economic outcomes. Thus our results suggest that decreased political efficacy may explain in part why Blacks' economic outcomes are decreasing in segregation. ${ }^{6}$

We present these results in detail, after describing the data and methodology in the next section.

II Data and Methods

II.A Sample

We examine the changing relationship between segregation and political outcomes across decades. Our focal period is $1973^{7}-2002$, which includes every completed redistricting period since the Voting Rights Acts of 1964 and 1965 outlawed literacy tests and other barriers to Black enfranchisement.

Our unit of observation in each decade is the Metropolitan Statistical Area (MSA). ${ }^{8}$ We focus on the MSA for two reasons: First, The MSA is not a political unit. Political boundaries, most notably congressional districts, are defined by the individuals who hold political power. ${ }^{9}$ The relationship between segregation and political units may be endogenous. Thus we measure segregation at the MSA level, treating the configuration of the congressional districts to which MSA residents belong as an outcome variable. Second, a focus on MSAs avoids a second source of endogeneity: intra-urban

\footnotetext{
${ }^{6}$ We recognize, however, that the direction of causation may also run from economic outcomes to civic efficacy.

${ }^{7}$ We also include the 1972 election which chose the members of the $93{ }^{\text {rd }}$ Congress which commenced in 1973.

${ }^{8}$ A Metropolitan Statistical Area is comprised of a county or set of counties that contain a central city of at least 50,000 inhabitants "plus adjacent counties with a high degree of integration with the central county as measured by commuting” (Office of Management and Budget 2000, 82238).

${ }^{9}$ States are political units whose boundaries are not decided by those who currently hold power. However, many states are too large (and contain too many areas in which Blacks do not reside) to speak about state segregation meaningfully. Nearly 90\% of Black Americans live within an MSA. (McKinnon 2003).
} 
residential sorting (Cutler and Glaeser 1997). For example, the most politically

efficacious Blacks may choose to live in the least segregated parts of the metro area.

More specifically, we examine outcomes for $312^{10}$ MSAs identified by Cutler and Glaeser (1997) as having more than 1000 Black residents in the 1990 Census. One difficulty in comparing MSAs from decade to decade is that MSA definitions change with each census. We overcome this limitation by holding our MSA definitions constant ${ }^{11}$ as we trace political outcomes back to the 1970 's.

\section{II.B. Segregation Indexes}

Our primary measure of segregation is the dissimilarity index, defined as

(1) Index of dissimilarity $=1 / 2 \sum_{i=1}^{N}\left|\frac{\text { black }_{i}}{\text { black }_{\text {total }}}-\frac{\text { nonblack }_{i}}{\text { nonblack }_{\text {total }}}\right|$

where $i=1 \ldots N$ is the array of census tracts in the area. According to this measure, the level of segregation in our sample has fallen across the three decades. The first row of Table I shows mean dissimilarity for 1970, 1980 and 1990. The value of .69 in the first cell of the table indicates that in 1970 69\% of the Black population would have had to relocate to different census tracts for there to be an even proportion of Black residents throughout the average MSA. By 1990 that figure had dropped to 56\%. While the average level of segregation has fallen over time, the ordering of cities from most segregated to least segregated has remained fairly stable, indicated by a correlation between 1970 and 1990 dissimilarity of .75. Our 1990 dissimilarity values come from Cutler, Glaeser and Vigdor (1999). We calculate the 1970 and 1980 indexes, using the

\footnotetext{
${ }^{10}$ Cutler and Glaeser (1997) identify 313 MSAs with black populations greater than 1000 . We eliminate the District of Columbia MSA because residents of the District do not elect any voting members to Congress.

${ }^{11}$ We maintain the 1990 definitions throughout. MSAs are defined by counties outside of New England and by towns within. We simply define the same set of counties/towns as an MSA in the three decades.
} 
1990 MSA definitions, with Census data for these years. ${ }^{12}$ Results are not contingent on our measure of segregation. An alternative measure of segregation, the isolation index, represents the percentage of Black residents in the average tract in which Blacks live. Our results are robust to the substitution of the isolation for the dissimilarity index.

\section{II.C. Outcomes}

Government structures vary from town to town both within and across MSAs. Thus we focus on the United States House of Representatives, because representation in the House is a metric that is comparable nationwide. ${ }^{13}$ We measure Black political efficacy using both descriptive and substantive congressional outcomes. Descriptive representation is the extent to which a group is represented by individuals of that same group. However, descriptive representation does not always equal substantive representation, or representation by individuals who share the political interests of the group. ${ }^{14}$ Our outcomes are the following:

Descriptive Representation

1) Black Candidates: One measure of the extent to which Blacks are participants in politics is the fraction of congressional districts in which there is at least one Black candidate running for the House. District candidate race data, available only for the 1980s and 1990s, are from Washington (2006). The mean of this measure has

\footnotetext{
${ }^{12}$ Because the entire country was not fully census tracked until 1990, this procedure introduces additional measurement error as we move backwards in time. Twenty-nine MSAs in 1970 and 69 in 1980 did not include sufficient census tracts for us to calculate segregation indexes directly. For these MSAs we predicted the segregation index using the 1990 segregation level and the change in percent Black, percent in poverty, percent high school graduate and percent employed between 1970 (1980) and 1990.

${ }^{13}$ Additionally the sheer number of local governments - more than 10,000 cities, towns and countieswithin our MSAs makes a focus on local government outcomes infeasible.

${ }^{14}$ For example, imagine a state with 10 districts. Blacks make up $10 \%$ of the state population. If all Blacks are located in one district then that district will likely elect a Black representative. Yet, on average Blacks will not likely have their substantive interests met by this legislative delegation as Blacks only directly influence (through the vote) one tenth of their state's representatives.
} 
increased between the two decades. (See Table I for the decade by decade means of all outcome variables.)

2) Black Representatives: A stricter measure of participation in politics comes from looking to the election winners. Our second efficacy outcome is the fraction of Representatives who are Black.

\section{Substantive Representation}

3) Democratic Representatives: In two-party elections, Black Americans cast their votes in favor of the Democratic candidate 70 to $90 \%$ of the time (McDermott 1998). Hence, we take the fraction of Representatives who are Democrats as a measure of Black political efficacy. This measure is falling over our sample period. Democrats' majority (in terms of number of members) over Republicans in the House shrank from the 1970 s to the 1980 s and was overturned in the 1990s.

4) Leadership Conference on Civil Rights Voting Record Score: Representative party is a coarse measure of political views. In addition to party, we look at Representative voting on civil rights issues as rated by the Leadership Conference on Civil Rights (LCCR). ${ }^{15}$ LCCR is a liberal leaning interest group that chooses approximately ten to twenty congressional votes per session that the organization considers as crucial to promoting civil rights in this country. A representative's LCCR score in a particular session is the fraction of these votes in which the representative votes in accordance with the LCCR's position. ${ }^{16}$ This measure is increasingly correlated with Democratic representative over time. ${ }^{17}$

\footnotetext{
${ }^{15}$ The scores for the $91^{\text {st }}$ through $109^{\text {th }}$ Congresses are available on the LCCR website, www.civilrights.org.

${ }^{16}$ We do not adjust these scores for comparability across years as prescribed by Groseclose, Levitt and Snyder (1999). Such an adjustment would be inappropriate in this analysis because it relies on restrictions
} 
5) Congressional Black Caucus Voting Record Score: Civil rights is not the only category of legislation of interest to Blacks. ${ }^{18}$ We follow Cameron, Epstein and O’Halloran (1996) to create a second voting score based on the fraction of the ballots in which the legislator votes in agreement with the Congressional Black Caucus (CBC) ${ }^{19}$ Founded in 1969 by the then thirteen Black members of Congress, the CBC has as its goals "to positively influence the course of events pertinent to African Americans and others of similar experience and situation, and to achieve greater equity for persons of African descent in the design and content of domestic and international programs and services. ${ }^{20}$ Every Black member of Congress, since the CBC’s founding, with the exception of JC Watts (R-OK), has been a member. ${ }^{21}$ The caucus currently has 43 members. The mean of Representatives' average agreement with the Congressional Black Caucus has remained about .6 across decades.$^{22}$ This measure is highly correlated with LCCR score across time. ${ }^{23}$

in the changes in a representative's mean preferences from year to year. As we have no prior evidence on the relationship between segregation and representative preference, we are more comfortable allowing preferences to vary freely. Lack of comparability imposes no limitations in interpreting our regression coefficients as all average LCCR scores within a regression are composed of averages of the same congressional sessions. Nonetheless, across decades, LCCR scores are highly correlated (.84 or greater) with Poole and Rosenthal's inter-temporally comparable Nominate scores available at www.voteview.com.

${ }^{17}$ The correlation is .5 in the 1970s, .67 in the 1980s and .87 in the 1990s.

${ }^{18}$ In addition voting record scores compiled by interest groups have been criticized for including only the most polarizing votes. See for example Snyder (1992).

${ }^{19}$ Data on how each member of Congress voted in each roll call vote are available on Poole and Rosenthal's website www.voteview.com .

${ }^{20}$ Goals taken from the Congressional Black Caucus Website (http://www.cbcfinc.org/About/CBC/index.html).

${ }^{21}$ Non-Black members of Congress are not permitted to join. Membership restrictions obtained in a communication with Myra Dandridge, spokesperson for the Congressional Black Caucus, July 7, 2006.

${ }^{22}$ We limit our attention to only those votes in which $60 \%$ or more of the CBC voted in agreement. Our results are robust to a change from 60 to $100 \%$.

${ }^{23}$ The correlation is . 85 in the $1970 \mathrm{~s}, .82$ in the $1980 \mathrm{~s}$ and .91 in the $1990 \mathrm{~s}$. 
In order to merge MSAs with their congressional outcomes, we match an MSA's counties to its respective congressional district(s) for each congressional session. ${ }^{24}$ Because an MSA may contain more than one district ${ }^{25}$ we average outcomes across districts within an MSA to create MSA/Congress level outcomes. ${ }^{26}$ (We use the mean rather than the median following Cameron, Epstein and O’Halloran (1996) who argue that the scores represent probabilities of voting in favor of a piece of legislation.) Then, to attain our best estimate of efficacy within a redistricting period, we average across the five Congresses to create MSA/decade level outcomes.

The focus on the House of Representatives drives our definition of decades. The number of representatives that each state may send to the House is defined by the decennial census. The first election affected by each census is the election in the year ending with 2 following that census. For example, the number of districts per state calculated using the 1970 census was first relevant for the 1972 House elections. Those elected in 1972 served from January 1973 to January 1975. Thus we define our decades to include all elections and congresses based on the respective census. ${ }^{27}$ (Recall that the measures of segregation are also created using the census.)

\footnotetext{
${ }^{24}$ In the case of New England we do the match by county and by town. The county match may give an overestimate of the districts in the MSA because counties are not contained by MSA boundaries within New England. On the other hand towns may give an underestimate of the districts in the MSA because it is not possible to look up the correspondence between unincorporated areas within an MSA and a district. County/district correspondence comes from $103^{\text {rd }}$ Congressional District Geographic Entity File, 1990 (ICPSR 6425) and Census of Population and Housing, 1980, Congressional District Equivalency File, $99^{\text {th }}$ Congress. County/district correspondence for 1970, town/district correspondence for all years, and intra decennial redistricting correspondence come from Congressional District Atlas (multiple years).

${ }^{25}$ Or portions of more than one district.

${ }^{26}$ We would like to weight this average by the fraction of MSA residents who live in the district. Unfortunately, these data are only available for the districts created with the 1990 redistricting. For 1990 we run specifications using outcomes created by weighted averages as well as those created by simple averages. Results are robust to this change.

${ }^{27}$ Although the majority of congressional redistricting is done between the census year and the election that follows two years later, states are free to redistrict at any time. Therefore we match MSAs to districts by congressional session and not by decade.
} 


\section{II.D Methodology}

For each decade, we are interested in the following equation:

(2) outcome $_{i}=\alpha \imath+\beta_{1}(\text { segregation })_{i}+\beta_{2}(\text { perblk })_{i}+u_{i}$

where outcome is one of the political efficacy measures defined in the previous section, segregation is the dissimilarity score and perblk is the percent of the MSA's population that is Black. Blacks may be more efficacious where they are a larger percentage of the population. We condition on percent Black to isolate the effects of segregation, conditional on area ethnic heterogeneity. Previous literature has shown an association between demographic characteristics (such as education, poverty status, employment status and age) and political participation and political choice. (See for example Leighly and Nagler, 1992 and Wolfinger and Rosenstone,1980). However, we do not control for these demographics in our most basic specification because the demographic make up of the MSA is in fact endogenous to segregation. For example, Ananat (2007) shows that segregation affects the average level of education, income and even movement into an MSA. By omitting these endogenous demographics we capture the full effect of segregation on each outcome of interest (including any intermediary effects on demographic characteristics. $)^{28}$

The limitation of equation 2 is that the coefficient $\beta_{1}$ cannot be interpreted causally due to the potential endogeneity of segregation. For example, perhaps non-Black residents' preference for interactions with Blacks influences both the level of segregation and the level of Black efficacy--such an influence might lead our OLS results to be biased in a negative direction. Or perhaps the most politically active Blacks prefer to live

\footnotetext{
${ }^{28}$ Our 2SLS results are robust to the inclusion of controls for demographic characteristics, as we demonstrate in the results section.
} 
primarily among Blacks--such a preference might lead our OLS results to be biased in a positive direction. The great shortcoming of the OLS results is that we cannot even sign their bias.

We overcome this limitation by following a 2SLS approach; we instrument for segregation using Ananat’s (2007) railroad division index (RDI). Before the Great Migration, Blacks predominantly lived in former slave holding states. ${ }^{29}$ The RDI instrument exploits the fact that the Great Migration, the large movement of Blacks from the South to the North during the years 1915 to 1950 , occurred after the vast majority of the country’s present day railroad tracks had been laid. The more subdivisions within a city created by the tracks, the easier it was in that city to confine (segregate) Blacks in neighborhoods whose boundaries were defined by these tracks. The RDI is defined as (3) $R D I=1-\Sigma\left(\frac{\text { areai }}{\text { totalarea }}\right)^{2}$ where $i$ represents a subdivision of the central city of an MSA created by railroad track. ${ }^{30}$ An RDI of zero would mean that there are no tracks running through the MSA. An RDI of one would mean that the MSA is infinitely divided by railroads with each area having an area of near zero. ${ }^{31}$

Our first stage equation is (4) segregation $_{\mathrm{i}}=\alpha \imath+\delta_{1}(\mathrm{RDI})_{\mathrm{i}}+\gamma_{1}(\text { tracklength })_{\mathrm{i}}+\gamma_{2}(\text { perblk })_{\mathrm{i}}+\mathrm{u}_{\mathrm{i}}$.

\footnotetext{
${ }^{29}$ Ananat (2007) estimates that in 1910 90\% of Blacks still lived in former slave states of Delaware, Maryland, the District of Columbia, Virginia, West Virginia, North Carolina, South Carolina, Georgia, Florida, Alabama, Mississippi, Louisiana, Tennessee, Kentucky, Missouri, Texas and Arkansas.

${ }^{30}$ Ananat (2007) defines the center city as the four kilometer radius circle around the centroid of the population center in the early $20^{\text {th }}$ century. Such an approach means that historical variations in city size will not distort the RDI measure.

${ }^{31}$ Atack and Passell (1994) estimate that 75\% of total track in the United States had been laid by 1900. Nonetheless, to better capture the pre-Great Migration track configuration Ananat (2007) calculates the RDI using historical maps with a median year of creation of 1909.
} 
There is a mechanical relationship between tracklength and $R D I$. We therefore control for tracklength out of a concern that the amount of track laid in a city may relate to how prosperous the city was and therefore how desirable a location it was for, for instance, the most politically efficacious Blacks (Ananat 2007). (Our first stage estimates for the three decades are found in the first three columns of Table II.)

Our second stage is

(5) outcome $_{\mathrm{i}}=\alpha \boldsymbol{l}+\beta_{1}(\text { segregation })_{\mathrm{i}}+\beta_{2}$ (perblk) $)_{\mathrm{i}}+\beta_{3}$ (tracklength) $+\mathrm{u}_{\mathrm{i} .}$.

The assumption of our identification strategy is that RDI at the beginning of the twentieth century does not predict Black civic efficacy at the century's end, except through its effect on segregation. There are two obvious ways in which that assumption could be violated. First, RDI could be correlated with early twentieth century MSA characteristics which impact later twentieth century political efficacy. Second, the instrument may have a direct impact on Black civic efficacy or its correlates.

RDI does not predict early twentieth century MSA politics. Table III presents regressions of the percent of MSA voters ${ }^{32}$ casting ballots for the Democratic candidate in the six presidential elections that occurred between 1900 and 1920. The sample is the non-New England MSAs in our 2SLS sample. We omit New England because in that region MSAs are not defined by counties; the early twentieth century voting data is available by county. RDI is not a significant predictor of Democratic voting. Thus Table III provides no evidence that our instrument affects present day Black civic efficacy through an impact on early twentieth century politics.

\footnotetext{
${ }^{32}$ The denominator is the number who cast ballots for one of the two major parties.
} 
Ananat (2007) further demonstrates that RDI is not correlated with early twentieth century demographic and economic characteristics. Using the 1910 and 1920 censuses, she shows that RDI does not predict early century demographic descriptors of the population including population size, percent Black, level of European immigrant segregation, ${ }^{33}$ and physical size of the MSA. Nor does RDI predict early century economic outcomes such as the literacy rate, the number of street cars per capita, labor force participation rate and the share of employment in trade, manufacturing and railroads.

As stated above, an additional concern about our identification strategy is that RDI may have a direct impact on Black civic efficacy or its correlates. Ananat (2007) presents evidence that the instrument does not impact later twentieth century outcomes, except through its effect on segregation. The concern is that railroad configuration could impact land values and therefore residential income segregation. She provides evidence against this channel by demonstrating that RDI does not predict 1990 income segregation. ${ }^{34}$ Further, given her results of a positive relationship between RDI and White economic outcomes (in contrast to a negative relationship between RDI and Black economic outcomes), Ananat (2007) argues that RDI operates through race rather than through income.

One limitation of this identification strategy is that we can only create the instrument for those MSAs which meet two criteria: 1) They are not located in former

\footnotetext{
33 European ethnic immigrant segregation was then at its historical peak, according to Massey and Denton (1993). Its historical peak was quite low relative to the historical peak of black segregation-the maximum isolation index was 0.39 for Italians in Worcester, MA, in 1910 (Vigdor 2006); by contrast, the median isolation index for blacks in 1970 was .37.

${ }^{34}$ Income segregation is insignificant in the U.S. relative to racial segregation; the highest dissimilarity index for income in 1990 is .28, while the lowest 1990 dissimilarity for African-Americans is .33.
} 
slave states and 2) Ananat (2007) was able to locate an historical map to calculate the RDI for the MSA. ${ }^{35}$ Therefore our 2SLS results will be limited to only 121 of the 312 MSAs in our full sample. ${ }^{36}$ In terms of segregation, representative race and representative voting patterns, the full sample and the 2 SLS sub-sample are quite comparable. ${ }^{37}$ The final three columns of Table I provide the means for the 2SLS sample. However, reflecting the fact that slightly more than half of Blacks continue to live in the South, ${ }^{38}$ percent Black is smaller in the 2SLS sample than in the full sample. In the next section we detail our results.

III Results

\section{III.A. Political Efficacy}

Segregation had a negative impact on Black civic efficacy in the 1990s, results in Table IV indicate. Each cell in the table presents the coefficient on the dissimilarity index from a different regression specification. Each row reflects a different outcome; each column reflects a different specification. The first three columns provide the results from OLS regressions on the full sample, the non-South sample and the 2SLS sample. While these results are not interpretable causally due to the endogeneity of segregation, they serve to indicate the extent of generalizeability of our 2SLS results. As we move from a sample of MSAs from across the nation to the non-South sample, although all results are insignificant, coefficients vary considerably. One coefficient changes sign. Three of five change by an order of magnitude. As we noted in the data and methods section, Ananat

\footnotetext{
${ }^{35}$ There are 77 non-Southern MSAs for which Ananat (2007) could not locate a map.

${ }^{36}$ See Appendix Table I for a list of the MSAs included in the 2SLS analysis.

${ }^{37}$ With the exception of the fraction Black candidates in 1990. The 1990 redistricting created 13 new safe Black districts, all in southern states. (Clayton 2000).

${ }^{38}$ Fifty-four percent of Blacks lived in the South in March 2004. (U.S. Census Bureau, Current Population Survey, Annual Social and Economic Supplement 2004, Racial Statistics Branch, Population Division.)
} 
(2007) was not able to locate historical maps for all non-southern MSAs. As we move from column 2 (all non-southern MSAs) to column 3 (non-southern MSAs for which we have the RDI instrument), coefficients are more stable. Thus while our results can likely be generalized to the non-South, generalizing to MSAs in the South seems less tenable on empirical as well as theoretical grounds. Previous research has found that the politics of race differs between the South and the non-South (Massey and Denton 1994; Cameron, Epstein and O’Halloran 1996).

Column 4 provides evidence of the causal impact of segregation on Black civic efficacy outside of the South. Regardless of how efficacy is measured, the relationship between segregation and efficacy is negative, although not always statistically significant. The first row of the table indicates that as segregation increases, Blacks seem to participate less in the political process. The -.441 in the first row of the table implies that as segregation increases by .10, the fraction of Black House candidates decreases by .04 . Alternatively as segregation increases by a standard deviation the fraction of Black House candidates decreases by a significant .47 standard deviations. Moving down the row, a one standard deviation increase in segregation in an MSA causes the fraction of Black representatives to fall by a significant .63 standard deviations, the fraction of Democratic representatives to fall by .59 standard deviations, the average representative's LCCR score to fall by a significant .82 standard deviations and the average representative's propensity to vote in accordance with the Congressional Black Caucus to fall by.72 standard deviations. For aid in interpreting the score results, note that a standard deviation in LCCR (or CBC) score separates a staunch Republican like former Representative Robert Barr (R-GA), who was a leader in the fight to impeach President 
Clinton, from a moderate Republican like former Representative Robert Simmons (RCT), who lost his seat in the 2006 election. Moderate Democrat former Representative Gary Condit (D-CA) is also separated by a standard deviation on these scores from Representative Nancy Pelosi (D-CA), the first female speaker of the House of Representatives. ${ }^{39}$

The remainder of the table provides the results of various checks to our basic specification.The number of Blacks living in each MSA varies considerably. Therefore it is possible that our column 4 results reflect a relationship that predominantly prevails in MSAs in which few Blacks actually live. We investigate whether such heterogeneous treatment effects are driving our findings in specifications reported in column 5. Specifications reported in this column are the basic specifications weighted by the log of the number of Black residents of the MSA. We choose to weight in logs rather than levels because we are uncomfortable allowing an MSA's influence on our estimation to be proportional to the size of its Black population due to the presence of three outlier MSAs with Black populations an order of magnitude greater than the sample mean. ${ }^{40}$ Our results are robust to the change from the unweighted to the weighted specification as indicated by the results of column 5 . Thus our basic results do not seem to be driven by MSAs in which few Blacks actually reside. (Results are also robust to the exclusion of the three outlier MSAs.)

As indicated in the data and methods section, district outcomes are averaged to form MSA level outcomes. For the 1990s only, we have data that allow us to population-

\footnotetext{
${ }^{39}$ These differences calculated based on the $107^{\text {th }}$ Congress, the most recent term included in our analysis. ${ }^{40}$ In the 2SLS sample the average number of Blacks in an MSA in 1990 is approximately 50,000. Three MSAs_-Detroit, Philadelphia and Los Angeles—have Black populations of greater than 500,000. Level weighted regressions would essentially be driven by these three MSAs.
} 
weight our averages to form a better measure of the representation that the average MSA resident faces. ${ }^{41}$ The final column of the table presents the coefficients from specifications which use the population-weighted measures. In terms of both magnitude and significance, coefficients are little changed from column 4 to column 6, indicating that our column 4 results are not driven by our weighting procedure. Thus we can be more confident in our results as we trace the impact of segregation back through the 1970s.

Looking back across decades, we learn that segregation has had a consistent negative impact on Black civic efficacy since the first redistricting following the Voting Rights Act. See Table V Panel A for these results. Once again, each cell represents the coefficient on the dissimilarity index from a different regression. Each row presents a different outcome; each column presents the results from the basic specification using data from a different decade. Point estimates indicate that a one standard deviation increase in segregation decreases the fraction of Black House candidates by $1 / 2$ to 1 standard deviation, the fraction of Black House members by $3 / 4$ of a standard deviation, the fraction of Democrats by $1 \frac{1}{2}$ to $1 \frac{1}{4}$ standard deviations and the average LCCR and CBC scores by about one standard deviation. While the point estimates suggest that this negative relationship shrinks in magnitude over time, for none of these three outcomes can we distinguish between the 1970 and the 1990 coefficient statistically. Although only 9 of 14 coefficients are statistically significant, the consistency of the sign of the results is evidence of the enduring negative impact of segregation on Black political outcomes. In Appendix Table II we demonstrate the robustness of the results to additional controls. The additional covariates decrease precision, but leave the pattern of results unchanged.

${ }^{41}$ Weights are based on initial-1992_redistricting. 


\section{III.B. Mechanisms}

Individuals’ political viewpoints are aggregated to form area-wide political outcomes in a multi-staged process. First, a citizen must form a viewpoint. Second, that citizen must decide whether it is worth his or her while to make the effort to express that viewpoint in the voting booth. Thirdly, the citizen's vote (if cast) must be aggregated with others' votes according to institutional regulations to determine the winning policy. ${ }^{42}$ (In the case of House races, the institutional regulations say that votes are summed, and representatives are therefore chosen, by district.)

At what point(s) in this process are Blacks in more segregated MSAs falling behind those Blacks living in less segregated MSAs? Is it that Black/non-Black political viewpoints are more divergent in more segregated metropolitan areas? Are Blacks’ feelings of political efficacy (and therefore their belief in the value of voting) decreasing in segregation? Are non-Blacks' feelings of efficacy increasing in segregation? Or are the political institutions — the districts — designed in a manner that is less conducive to Black substantive representation in more segregated areas?

In the remainder of the paper we trace the process backward from political outcomes to the development of political viewpoints to examine at what point(s) segregation causes Blacks to be less efficacious.

\section{III.B.1. Redistricting}

While the process of redistricting varies from state to state, in no state is the process determined orthogonally to the racial composition of the neighborhoods within. Federal case law stipulates that districts be compact and contiguous (Stokes 1998).

\footnotetext{
${ }^{42}$ We ignore a fourth step where the elected politician must choose whether to enact the policy that the people desire. We assume, given its repeated game nature, that House members do enact the will of the people on average.
} 
Therefore the extent of segregation in neighborhoods may mechanically impact upon the racial composition of districts. Given that it is a federal requirement that redistricting schemes provide "equality of opportunity” for minority voters (Stokes 1998) there is little doubt that state legislatures pay attention to the racial makeup of the districts when deciding whether to approve any proposed districting plan. Thus rather than treat the districts as exogenous, we empirically estimate the relationship between Black/non-Black racial segregation and district racial composition.

There is a long literature in political science debating the implications of district demographic composition for Black political efficacy. (See Grofman and Davidson 1992 for an overview.) In the most extensive empirical examination of the question to date, Cameron, Epstein and O’Halloran (1996) investigate the relationship between a district's percentage of Black voters and its representative's party and LCCR score. Using their estimates in simulation, the authors conclude that in all parts of the United States with the exception of the South ${ }^{43}$ the optimal strategy for maximizing Black representation in an area is to equalize the Black population across districts within that area. ${ }^{44}$

In Table V Panel B we examine the extent to which segregation predicts the spread of Blacks in districts throughout a metropolitan area. ${ }^{45}$ It is possible that Blacks are less efficacious in more segregated areas because, following the reasoning of Cameron, Epstein and O’Halloran (1996), Blacks are confined to more heavily Black

\footnotetext{
${ }^{43}$ In the South, the optimal strategy, according to Cameron, Epstein and O’Halloran (1996), is to create as many districts of about $47 \%$ Black as possible.

${ }^{44}$ Cameron, Epstein and O’Halloran (1996) used states as the area of investigation; however, as one vote in Congress is equal to any other vote in Congress, the aggregation of representatives to states in no way drives their simulation results. Therefore their results should be applicable to delegations that represent metropolitan areas as well. Nonetheless, the political reality is that the redistricting process is controlled by the state legislature and districts must fall within state boundaries. So for MSAs that cross state boundaries, it may not be possible to equalize percent Black throughout the MSA. This constraint, however, does not alter the relationship between equalization of percent Black within an area and Black efficacy.

${ }^{45}$ See Appendix Table III for means to accompany this Table V Panel B.
} 
districts in these metro areas. To investigate this supposition we continue to run models of the form of Equation 5 where our outcomes are now measures of the demographic characteristics of the districts within the MSA. ${ }^{46}$ The first row of the panel examines the influence of segregation on the fraction of districts in which Blacks comprise less than 10 percent of the population. Blacks are 5-6 percent of the population in the average district in the 2SLS sample. Thus negative coefficients on segregation in these regressions would indicate that in more segregated MSAs Blacks are less likely to be spread evenly across districts, which would be one explanation for their efficacy decreasing in segregation. However, as the results of the first row of the table indicate, segregation is positively and significantly associated with the fraction of districts that are under 10 percent Black in all three sample periods. We consider districts that are more than 10 percent Black as "heavily" Black for our northern sample, where only 5-10 percent of districts fall in this category. But there is heterogeneity in percent Black amongst this group of districts. In an un-tabled regression we create dummies for $0-10,10-25,25-50$ and 50 or more percent Black to allow for the impact of segregation to differ across the three categories of "heavily" Black districts. We find no such variation. Blacks in more segregated MSAs are significantly less likely to be living in districts that are 10-25 percent Black. The signs are mixed and insignificant on 25-50 and 50 and higher percent Black. Thus we find no evidence that segregation lessens Black efficacy by isolating Blacks in heavily Black districts.

In the final row of Table V we measure the spread of Blacks across districts within an MSA using a different metric: the standard deviation of the districts' percent

\footnotetext{
${ }^{46}$ Because of data limitations, we are unable to measure the percent Black for each redistricting that occurs. Therefore we measure these outcomes once per decade, at the time of the first election following the most recent census.
} 
Black. (The limitation of this measure is, of course, that it is not defined for MSAs whose residents are all assigned to the same district.) Once again, we find no evidence of segregation increasing the variation in percent Black across districts. In fact the relationship between segregation and standard deviation is negative, although insignificant, across the three decades. Cameron, Epstein and O’Halloran (1996) assert that substantive representation of Blacks is decreasing in the standard deviation of district percent Black in an area. Assuming their assertion correct, the results of Table V Panel B provide no evidence that district configuration is the mechanism by which segregation has lessened Black political efficacy across three decades. ${ }^{47}$

\section{III.B.2 Voter Turnout}

A second possible mechanism by which segregation may impact Black civic efficacy is through political participation, particularly in the form of voting. Ananat (2007) shows that segregation significantly increases the rate of poverty amongst Blacks while significantly decreasing the poverty rate amongst Whites. We know from previous work that lower-income subgroups are less likely to vote. (See for example Leighly and Nagler, 1992.) Thus it may be the case that segregation decreases Black voter turnout and/or increases non-Black voter turnout, resulting in a decrease in Black civic efficacy. ${ }^{48}$

We examine the impact of segregation on voting behavior (as well as political attitudes) using data from the National Election Studies (NES), a biennial survey of

\footnotetext{
${ }^{47}$ We also investigated the possibility that non-MSA residents who share districts with MSA residents may be more (less) sympathetic to Black political interests and therefore driving the relationship between segregation and Black civic efficacy. However we find no support for such a hypothesis. We find no evidence that more segregated MSAs are carved into significantly more/fewer districts than less segregated MSAs. These findings are not surprising given that our results in Table IV are not altered significantly by population weighting outcomes.

${ }^{48}$ This is just one mechanism by which segregation could impact turnout. Coate and Conlin's (2004) group rule utilitarian model suggests that segregation could impact turnout because in a segregated area it may be easier to enforce group norms.
} 
United States residents of voting age. Using these data we run 2SLS models, separately

for Black and non-Black respondents, of the following form:

(6) outcome $_{\mathrm{i}}=\alpha \imath+\beta_{1}(\text { segregation })_{\mathrm{i}}+\beta_{2}$ (tracklength $)_{\mathrm{i}}+\mathrm{u}_{\mathrm{i} .}$.

(7) segregation $_{i}=\alpha l+\delta_{1}(\mathrm{RDI})_{\mathrm{i}}+\gamma_{1}(\text { tracklength })_{\mathrm{i}}+\mathrm{u}_{\mathrm{i}}$

where segregation is now the predicted level of segregation in the respondent's MSA. ${ }^{49}$ We conduct our analyses separately by decade ${ }^{50}$ and by racial group: Black and nonBlack. When possible, we substitute the first wave of the National Survey of Black Americans, fielded in 1979-1980, for the 1970 Black NES sample, in which our first stage was not significant. (See Appendix Table IV.)

Across decades, we find no significant relationship between segregation and voter turnout of either Blacks or non-Blacks. (See the first row of Table VI for these results). Further, point estimates do not support the contention that the segregation/civic efficacy link runs through turnout. The relationship between segregation and turnout is not significant, except for Blacks in the 1970s, when it is positive. Thus we find no support for the supposition that segregation decreases Black efficacy by increasing non-Black turnout and/or decreasing Black turnout.

\section{III.B.3. Political Attitudes}

Thus far our findings suggest that neither district configuration nor racial variation in turnout accounts for segregation's negative impact on Black political efficacy. A third explanation is that political views of Blacks and non-Blacks are more divergent in more segregated areas. Blacks are not a majority of residents in any time or

\footnotetext{
${ }^{49}$ We use respondents' states and congressional districts to match them to our time invariantly defined MSAs. In cases where a district lies in more than one MSA we define the respondent's level of segregation as the average segregation in the MSAs. Reported regression results are thus clustered at the district level. However, the significance of our results is robust to clustering at the state level.

${ }^{50}$ We define the survey years $1972-1980$ as the 1970 s, $1982-1990$ as the 1980 s and $1992-2000$ the 1990 s.
} 
place in our sample frame. Therefore, as non-Black political views move increasingly far from Black political views, by definition, Blacks move farther away from the mean (and likely the median) viewpoint. We examine the evidence for the divergent views explanation in the remainder of Table VI. In this table we continue to present the results from models of the form of equations 6 and 7 using the NES (and NSBA where possible.)

In the second panel of the table entitled "Attitudes toward Race” we explore the impact of segregation on racial tolerance and support for policies which benefit Blacks. Our first outcome is non-Black respondents' feelings about Blacks measured on a scale of 0 (very negative) to 100 (very positive). The -.889 coefficient in the 1970 s regression is unfortunately too imprecise to be informative. However, the 1980s and 1990s coefficients say that an increase in segregation of one standard deviation results in a significant decrease in non-Black feelings about Blacks of .06 and .18 standard deviations respectively. ${ }^{51}$ In the remainder of the row we examine Black feelings toward Whites (the largest non-Black subgroup). Point estimates suggest that feelings about Whites are increasing in segregation in the 1980s and decreasing in segregation in the 1990s. However, all estimates are far too imprecise to be informative.

Next, we examine how segregation impacts feelings about race-based policy. The focal question asks respondents whether they support government policies to improve the social and economic position of Blacks. Respondents were asked to place themselves on a seven point scale from a low of 1 (Government should help Blacks) to a high of 7 (Blacks should help themselves). ${ }^{52}$ Non-Blacks have a mean score for the measure of between four and five across decades. However, across time, Blacks increasingly support

\footnotetext{
${ }^{51}$ See Appendix Table V for means and standard deviations to accompany Table VI.

${ }^{52}$ Prior to 1988, the question asked about "Blacks (Negroes) and other minority groups.” Beginning in 1988, the question focused solely on Blacks.
} 
the view that Blacks should help themselves (from a mean of 2.3 in the 1970 s to 3.8 in the 1990s). Point estimates of the impact of segregation on this belief suggest that the tendency, among non-Blacks, to believe that Blacks should help themselves is increasing in segregation across decades. The relationship is significant in the 1980s and 1990s, when a one standard deviation increase in segregation predicts an increase in this belief of .11 and .17 standard deviations respectively. Results for Blacks, though never significant, are opposite signed from non-Blacks in the 1980s and near zero in the 1990s. Thus the "Attitudes toward Race” panel provides evidence that the relationship between segregation and Black civic efficacy may be driven by non-Black support for Blacks and policies that favor Blacks, as this support is decreasing in segregation.

Next we look at the impact of segregation on political attitudes more generally. The first outcome of interest is the respondent's view of how liberal/conservative s/he is on a scale from 1 (extremely liberal) to 7 (extremely conservative). Across decades, the non-Black mean on this measure has hovered around 4.3 while the Black mean has grown from 3.3 to 3.8. Reported in the first row under "Political Attitudes," point estimates from specifications using this outcome suggest that, across decades, polarization in political views is increasing in segregation. While conservative identification is increasing in segregation amongst non-Blacks, liberal identification is increasing in segregation amongst Blacks. The relationship is significant only for nonBlacks in the 1980s and 1990s, where a one standard deviation increase in segregation increases the mean tendency toward conservatism by .18 and .27 standard deviations respectively. 
The second more general political attitude we examine is party identification. The NES asks respondents to place themselves on a scale from 1 (strong Democrat) to 7 (strong Republican). Not surprisingly, given Blacks’ tendency to vote Democratic, across decades, the mean of this measure is approximately four for non-Blacks and two for Blacks. Amongst non-Blacks we see that segregation increases the tendency to identify as Republican; coefficients indicate a significant relationship for the 1970s and 1990s, when a one standard deviation increase in segregation increases Republican identification by .4 and .14 standard deviations respectively. Identification translates into behavior, or at least reported behavior, as the results of the final row of the table demonstrate a significant negative relationship between segregation and votes for the Democratic Party, in 1970 and 1990. The impact of segregation on Black party identification and vote choice are unclear, as insignificant coefficients flip signs across the decades.

Thus the results of Table VI suggest that political attitudes may explain the relationship between segregation and decreased Black civic efficacy. Segregation increases non-Blacks' tendency to identify and vote conservatively and to oppose policies that favor Blacks. Point estimates suggest that segregation, on the other hand, increases Blacks' tendency to identify as liberals. This evidence points not only to an explanation for decreased efficacy for Blacks in more segregated areas, but also suggests that Blacks in the most segregated areas are less efficacious than our Table V results suggest. Black liberal identification is increasing in segregation, while the tendency for representatives to vote liberally on issues of interest to Blacks is decreasing in segregation.

Such divergence could come about in either or both of two ways: 1) Increased contact with Blacks in less segregated cities could cause non-Blacks to hold more 
favorable views toward policies which benefit Blacks. This could arise because of interactions with Black neighbors as postulated by the contact hypothesis ${ }^{53}$ or from a feeling that they will benefit more directly from policies that benefit Blacks when they live nearer to Blacks. 2) Alternatively, the link between segregation and efficacy may be due to selection. Non-Blacks who hold the least favorable views toward policies which Blacks support may choose to live in the most segregated cities.

Distinguishing between these two mechanisms is important for understanding the impact of segregation on Black political efficacy nationally. If segregation causes decreased efficacy through lack of contact, then increased segregation in MSA 1 will decrease Black efficacy in MSA 1 and therefore Black efficacy nationally, on average. If segregation causes decreased efficacy through selection, then increased segregation in MSA 1 will decrease efficacy in MSA 1 but may increase efficacy in MSA 2 as those who hold the least favorable views of policies that Blacks support move from MSA 2 to MSA 1. Distinguishing between contact and selection, however, is not important for understanding the effects of segregation on those individuals who face budget constraints that prevent their relocating from MSA 1 to MSA 2.

In Table VII we investigate whether selection and/or contact explain the impact of segregation on Black political efficacy. The first three columns of the table focus on selection. In these columns, we repeat the attitudinal analysis of Table VI; however, we limit the sample to those non-Black individuals ${ }^{54}$ over the age of 30 who moved to the

\footnotetext{
${ }^{53}$ See for example Brophy (1945), Deutsch and Collins (1951), Jackman and Crane (1986), Putnam (1966) and Wilner et. al. (1952).

${ }^{54}$ We do not perform this exercise for Blacks due to the small sample size.
} 
community ${ }^{55}$ within the past two years. In other words, we focus on adults who recently selected to live in the area. Looking at the first measure, the Black thermometer, we find in both the 1970s and 1980s, the relationship between selecting a more segregated area and attitude toward Blacks is insignificant. However, in the 1990s we find that those who have chosen more segregated areas have significantly more negative ratings of Blacks. In fact in the 1990s, for four of five attitudinal outcomes we find that individuals who select more segregated areas hold significantly more conservative views than those who select less segregated areas. At least for the 1990s, it appears that selection does play a role in linking segregation and decreased Black political efficacy.

In the final three columns of Table VII we explore whether contact (or lack thereof) is another path from segregation to efficacy. The ideal methodology for exploring this question would be to randomly assign individuals to communities. Boisjoly et. al (2006) use such a methodology to find that white college students who, in their first year of school, were randomly assigned Black roommates, hold more positive views of affirmative action several years after college entry than those who were assigned white roommates. But whether these results are generalizeable to the community level is unknown. Unable to randomly assign individuals to MSAs, we focus our contact analysis on non-Black individuals thirty years of age and younger. ${ }^{56}$ Younger individuals have had less of an opportunity to leave the locale that their parents chose for them and to move to their ideal community. Clearly two limitations of this methodology are that: 1 ) Some younger individuals have relocated from their parents’ hometowns (or made a

\footnotetext{
${ }^{55}$ The NES asks, "How long have you lived here in your present city/town/township/county?” The measure is less than ideal for our purposes as a respondent may move to a different county but remain in the same MSA.

${ }^{56}$ The somewhat more convincing strategy of relating attitudes to MSA of birth is not possible because the NES identifies only state, but not MSA or county or district, of birth.
} 
deliberate decision to stay) and 2) The parents did select these communities. For these reasons the results of the second half of Table VII are only suggestive.

The Table VII column 4-6 results suggest that contact affects non-Blacks' attitudes toward Blacks. We see in the 1990s that young people who live in more segregated areas have significantly less positive views of Blacks. The results on the remaining attitudinal outcomes are less informative. Coefficients are not significantly different than the significant results we find for the full sample, suggesting that those who were placed in more segregated communities developed more conservative attitudes than those placed in less segregated communities. However, results are imprecise and insignificant. Thus the results of Table VII show that selection (at least in the 1990s) plays a role in the impact of segregation on non-Black attitudes and therefore Black political outcomes. The table provides some evidence, particularly in regards to nonBlacks' views of Blacks, that segregation also impacts attitudes through decreased contact amongst the races.

\section{Conclusion}

Blacks in more segregated metropolitan areas fare worse than their counterparts in less segregated areas on a variety of economic outcomes. In this paper, we explore the connection between segregation and political efficacy, an outcome that to our knowledge has not been studied in relation to segregation.

We find that Black political efficacy (as measured by the ability to elect representatives who vote in accordance with the preferences of Black voters) is decreasing in segregation. This result does not arise because of differential district configuration or because of differential voter turnout by race. We do find evidence that 
the efficacy result is due to variation in attitudes. Non-Blacks have more conservative political views in more segregated areas. Given the belief in this country in the ability to effect change through political activity, our results may explain in part why Blacks’ economic outcomes are decreasing in segregation. 


\section{References}

Ananat, Elizabeth (2007). "The Wrong Side(s) of the Tracks: Estimating the Causal Effects of Racial Segregation on City Outcomes.” NBER Working Paper 13343.

Atack, Jeremy; Passell, Peter (1994). A New View of American Economic History, $2^{\text {nd }}$ Edition. New York, NY: W.W. Norton and Company.

Bobo, Lawrence (1988). “Group Conflict, Prejudice, and the Paradox of Contemporary Racial Attitudes.” In Eliminating Racism: Profiles in Controversy, ed. Phyllis Katz and Dalmas A. Taylor. New York: Plenum Press, 85-114.

Boisjoly, Johanne, Greg Duncan, Michael Kremer, Dan Levy and Jacque Eccles. (2006). “Empathy or Antipathy? The Role of Diversity.” American Economic Review, 96 (5) 1890-1905.

Brophy, Ira (1945-6). “The Luxury of Anti-Negro Prejudice.” The Public Opinion Quarterly, 9 (4) 456-466.

Cameron, Charles, David Epstein, and Sharyn O’Halloran (1996). “Do Majority-Minority Districts Maximize Substantive Black Representation in Congress?” American Political Science Review 90 (December): 794-812.

Clayton, Dewey (2000). African Americans and the Politics of Congressional Redistricting, New York: Garland Publications.

Coate, Stephen and Michael Conlin (2004). "A Group Rule-Utilitarian Approach to Voter Turnout: Theory and Evidence.” American Economic Review, 94 (5) 1476-1504.

Costa, Dora L., and Matthew E. Kahn. 2003. "Civic Engagement and Community Heterogeneity: An Economist's Perspective.” Perspectives on Politics 1 (March): 103111.

Cutler, David M.; Glaeser, Edward L. (1997). “Are Ghettoes Good or Bad?” Quarterly Journal of Economics, 112( 3): 827-72.

Cutler, David M.; Glaeser, Edward L.; Vigdor, Jacob L. (1999). "The Rise and Decline of the American Ghetto.” Journal of Political Economy, 107(3): 455-506.

Deutsch, Morton and Mary Collins (1951). "The Effect of Public Policy in Housing Projects upon Interracial Attitudes.” In Basic Studies in Social Psychology, ed.

Proshansky, Harold and Bernard Seidenberg, New York: Holt, Rinehart and Winston.

Grofman, Bernard, and Chandler Davidson, eds. (1992). Controversies in Minority Voting: The Voting Rights Act in Perspective. Washington, DC: Brookings Institution. 
Groseclose, Timothy; Steven Levitt; James Snyder (1990). "Comparing Interest Group Scores Across Time and Chambers: Adjusted ADA Scores for the US Congress.” American Political Science Review, 93 (1) 33-50.

Jackman, Mary and Marie Crane (1986). “'Some of My Best Friends are Black...' Interracial Friendship and Whites’ Racial Attitudes,” The Public Opinion Quarterly, 50 (4) 459-486.

Johnson, Martin, W. Phillips Schively, and Robert M. Stein (2000). “Accessibility and Contextual Explanations of White Racial Attitudes.” Paper presented at the annual meeting of the American Political Science Association, Washington, DC.

Johnson, Martin, W. Phillips Schively, and Robert M. Stein (2001). “Contextual Explanations of Presidential Vote Choice.” Paper presented at the annual meeting of the Midwest Political Science Association, Chicago.

Leighley, Jan E., and Jonathan Nagler (1992). "Socioeconomic Class Bias in Turnout, 1964-1988: The Voters Remain the Same.” American Political Science Review 86 (September): 725-736.

Massey, Douglas S.; Denton, Nancy (1993). American Apartheid: Segregation and the Making of the Underclass. Cambridge, MA: Harvard University Press.

McDermott, Monika L. (1998) "Race and Gender Cues in Low-Information Elections.” Political Research Quarterly 51 (12) 895-918.

McKinnon, Jesse (2003). “The Black Population in the United States: March 2002.” Current Population Reports, Series P20-541. Washington, DC: U.S. Census Bureau.

Office of Management and Budget (2000). "Standards for Defining Metropolitan and Micropolitan Statistical Areas, Notice.” Federal Register 65 (December 27): 8222882238.

Putnam, R. (1966). "Political Attitudes and the Local Community.” American Political Science Review, 60:640-54.

Stokes, Donald E. (1998). “Is There a Better Way to Redistrict?” In Race and Redistricting in the 1990s, ed. Bernard Grofman. New York: Agathon Press, 345-366.

Taylor , Marylee C. (1998). "How White Attitudes Vary with the Racial Composition of Local Populations: Numbers Count.” American Sociological Review 63 (August): 512535.

Vigdor (2006). Untitled working paper. 
Washington, Ebonya (2006). “How Black Candidates Affect Voter Turnout.” Quarterly Journal of Economics, 121 (3): 973-998.

Wilner, Daniel, Roxabelle Walkley and Stuart Coolk (1952). "Residential Proximity and Intergroup Relations in Public Housing Projects.” Journal of Social Issues, 8, 45-69.

Wolfinger, Raymond E. and Steven J. Rosenstone. 1980. Who Votes? New Haven, CT: Yale University Press. 
Table I: Sample Means by Decade

(Standard Deviations in Parentheses)

\begin{tabular}{|c|c|c|c|c|c|c|}
\hline & \multicolumn{3}{|c|}{ Full Sample } & \multicolumn{3}{|c|}{ IV Sample } \\
\hline & $1970 \mathrm{~s}$ & $1980 \mathrm{~s}$ & 1990s & $1970 s$ & $1980 \mathrm{~s}$ & 1990s \\
\hline \multicolumn{7}{|l|}{ Independent Variable of Interest } \\
\hline Dissimilarity Index & $\begin{array}{c}.69 \\
(.12)\end{array}$ & $\begin{array}{c}.60 \\
(.13)\end{array}$ & $\begin{array}{c}.56 \\
(.11)\end{array}$ & $\begin{array}{c}.70 \\
(.10)\end{array}$ & $\begin{array}{c}.60 \\
(.13)\end{array}$ & $\begin{array}{c}.57 \\
(.14)\end{array}$ \\
\hline \multicolumn{7}{|l|}{ Dependent Variables } \\
\hline 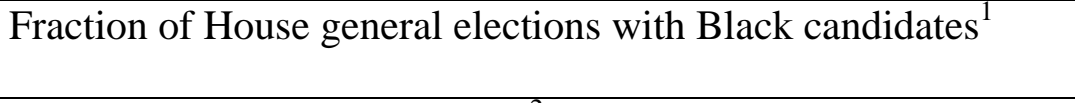 & NA & $\begin{array}{c}.03 \\
(.07)\end{array}$ & $\begin{array}{c}.07 \\
(.14)\end{array}$ & & $\begin{array}{c}.02 \\
(.05)\end{array}$ & $\begin{array}{c}.04 \\
(.13)\end{array}$ \\
\hline Fraction Black Representatives $^{2}$ & $\begin{array}{c}.01 \\
(.03)\end{array}$ & $\begin{array}{c}.01 \\
(.03)\end{array}$ & $\begin{array}{l}.04 \\
(.13)\end{array}$ & $\begin{array}{c}.01 \\
(.01)\end{array}$ & $\begin{array}{c}.01 \\
(.03)\end{array}$ & $\begin{array}{c}.02 \\
(.08)\end{array}$ \\
\hline Fraction Democratic Representatives ${ }^{2}$ & $\begin{array}{c}.60 \\
(.35)\end{array}$ & $\begin{array}{c}.56 \\
(.37)\end{array}$ & $\begin{array}{c}.43 \\
(.34)\end{array}$ & $\begin{array}{c}.51 \\
(.33)\end{array}$ & $\begin{array}{c}.50 \\
(.37)\end{array}$ & $\begin{array}{c}.41 \\
(.36)\end{array}$ \\
\hline Average Leadership Conference on Civil Rights (LCCR) score ${ }^{2}$ & $\begin{array}{c}.47 \\
(.25)\end{array}$ & $\begin{array}{c}.55 \\
(.25)\end{array}$ & $\begin{array}{c}.46 \\
(.25)\end{array}$ & $\begin{array}{c}.57 \\
(.24)\end{array}$ & $\begin{array}{c}.61 \\
(.26)\end{array}$ & $\begin{array}{c}.51 \\
(.27)\end{array}$ \\
\hline Average agreement with Congressional Black Caucus² & $\begin{array}{c}.60 \\
(.11)\end{array}$ & $\begin{array}{c}.62 \\
(.15)\end{array}$ & $\begin{array}{c}.59 \\
(.15)\end{array}$ & $\begin{array}{c}.63 \\
(.12) \\
\end{array}$ & $\begin{array}{c}.64 \\
(.17) \\
\end{array}$ & $\begin{array}{c}.60 \\
(.17)\end{array}$ \\
\hline \multicolumn{7}{|l|}{ Control } \\
\hline Percent Black & $\begin{array}{c}.09 \\
(.09) \\
\end{array}$ & $\begin{array}{c}.10 \\
(.09)\end{array}$ & $\begin{array}{c}.10 \\
(.09)\end{array}$ & $\begin{array}{c}.05 \\
(.04) \\
\end{array}$ & $\begin{array}{c}.05 \\
(.05) \\
\end{array}$ & $\begin{array}{c}.06 \\
(.05) \\
\end{array}$ \\
\hline Number of MSAs in Sample & 312 & 312 & 312 & 121 & 121 & 121 \\
\hline
\end{tabular}

Notes:

1 The decades are defined here as the elections of 1972-1980, 1982-1990 and 1992-2000.

2 The decades are defined here as the Congresses that spanned the years 1973-1982, 1983-1992, 1993-2002. 
Table II: First Stage, by Decade

\begin{tabular}{|l|l|l|l|}
\hline & 1970 & 1980 & 1990 \\
\hline Railroad Division Index & $.164^{* *}$ & $.212^{* *}$ & $.265^{* * *}$ \\
& {$[.064]$} & {$[.085]$} & {$[.087]$} \\
\hline $\mathrm{N}$ & 121 & 121 & 121 \\
\hline
\end{tabular}

Notes: Robust standard errors in brackets. Specifications control for track length and percent Black. ***denotes significance at the 1 percent level, ** at the 5 percent level and * at the 10 percent level.

1 The constant 1930 sample are those MSAs for which Cutler, Glaeser and Vigdor (1999) calculate segregation indexes and for which Ananat (2007) calculates RDI.

2 For 22 of 42 MSAs in the sample Cutler, Glaeser and Vigdor- (1999) do not provide 1950 segregation indices.

Table III: Relationship Between Instrument and Democratic share of Presidential Vote 1900-1920

\begin{tabular}{|l|c|c|c|c|c|c|}
\hline & 1900 & 1904 & 1908 & 1912 & 1916 & 1920 \\
\hline Railroad Division Index & $\begin{array}{c}0.057 \\
{[0.086]}\end{array}$ & $\begin{array}{c}0.082 \\
{[0.065]}\end{array}$ & $\begin{array}{c}0.087 \\
{[0.057]}\end{array}$ & $\begin{array}{c}-0.171 \\
{[0.130]}\end{array}$ & $\begin{array}{c}0.004 \\
{[0.053]}\end{array}$ & $\begin{array}{c}0.065 \\
{[0.049]}\end{array}$ \\
\hline Sample size & 94 & 94 & 96 & 99 & 99 & 99 \\
\hline
\end{tabular}

Notes: The sample does not include New England MSAs. All specifications control for length of track. Robust standard errors in brackets. 
Table IV: Impact of Segregation on Black Political Efficacy, 1990s

(Each cell represents the coefficient on the dissimilarity index from a different regression.)

\begin{tabular}{|c|c|c|c|c|c|c|}
\hline & \multicolumn{3}{|c|}{ OLS } & \multicolumn{3}{|c|}{ 2SLS } \\
\hline & $\begin{array}{l}\text { Full } \\
\text { Sample } \\
(1)\end{array}$ & $\begin{array}{l}\text { Non- } \\
\text { South } \\
(2) \\
\end{array}$ & $\begin{array}{l}\text { 2SLS } \\
\text { Sample } \\
(3)\end{array}$ & $\begin{array}{l}\text { Basic } \\
(4) \\
\end{array}$ & $\begin{array}{l}\text { Log } \\
\text { weighted } \\
\text { (5) } \\
\end{array}$ & $\begin{array}{l}\text { Outcomes population } \\
\text { weighted } \\
(6)\end{array}$ \\
\hline \multicolumn{7}{|l|}{ Outcome } \\
\hline Fraction Black House candidates & $\begin{array}{c}-0.043 \\
{[0.056]}\end{array}$ & $\begin{array}{l}-0.149 \\
{[0.118]}\end{array}$ & $\begin{array}{l}-0.202 \\
{[0.169]} \\
\end{array}$ & $\begin{array}{r}-0.441 \\
{[0.226]^{*}} \\
\end{array}$ & $\begin{array}{r}-0.434 \\
{[0.214]^{\star *}} \\
\end{array}$ & $\begin{array}{c}-0.432 \\
{[0.275]} \\
\end{array}$ \\
\hline Fraction Black Representatives & $\begin{array}{c}-0.018 \\
{[0.058]}\end{array}$ & $\begin{array}{l}-0.162 \\
{[0.120]}\end{array}$ & $\begin{array}{l}-0.217 \\
{[0.171]}\end{array}$ & $\begin{array}{c}-0.363 \\
{[0.206]^{*}}\end{array}$ & $\begin{array}{r}-0.362 \\
{[0.199]^{*}}\end{array}$ & $\begin{array}{r}-0.383 \\
{[0.227]^{*}}\end{array}$ \\
\hline Fraction Democratic Representatives & $\begin{array}{c}-0.166 \\
{[0.147]}\end{array}$ & $\begin{array}{c}-0.02 \\
{[0.234]}\end{array}$ & $\begin{array}{c}0.013 \\
{[0.294]}\end{array}$ & $\begin{array}{c}-1.524 \\
{[1.131]}\end{array}$ & $\begin{array}{c}-1.33 \\
{[0.990]}\end{array}$ & $\begin{array}{c}-1.617 \\
{[1.187]}\end{array}$ \\
\hline $\begin{array}{l}\text { Average Leadership Conference on } \\
\text { Civil Rights score }\end{array}$ & $\begin{array}{l}0.055 \\
{[0.109]}\end{array}$ & $\begin{array}{l}-0.016 \\
{[0.171]}\end{array}$ & $\begin{array}{c}-0.012 \\
{[0.214]}\end{array}$ & $\begin{array}{c}-1.596 \\
{[0.909]^{*}}\end{array}$ & $\begin{array}{r}-1.47 \\
{[0.789]^{*}}\end{array}$ & $\begin{array}{r}-1.638 \\
{[0.944]^{*}}\end{array}$ \\
\hline $\begin{array}{l}\text { Average agreement with Congressional } \\
\text { Black Caucus }\end{array}$ & $\begin{array}{c}-0.024 \\
{[0.065]}\end{array}$ & $\begin{array}{c}-0.027 \\
{[0.106]}\end{array}$ & $\begin{array}{l}-0.025 \\
{[0.131]}\end{array}$ & $\begin{array}{l}-0.882 \\
{[0.535]} \\
\end{array}$ & $\begin{array}{r}-0.809 \\
{[0.471]^{*}} \\
\end{array}$ & $\begin{array}{c}-0.904 \\
{[0.551]}\end{array}$ \\
\hline $\mathrm{N}$ & 312 & 190 & 121 & 121 & 121 & 121 \\
\hline
\end{tabular}

Notes: Robust standard errors in brackets. All regressions control for percent Black. Specifications 4-6 additionally control for length of track. ***denotes significance at the 1 percent level, ** at the 5 percent level and * at the 10 percent level. 
Table V: Two Stage Least Squares Estimates of the Impact of Segregation on Black Political Efficacy Across Decades (Each cell represents the coefficient on the dissimilarity index from a different regression.)

\begin{tabular}{|c|c|c|c|}
\hline & 1970s & 1980s & 1990s \\
\hline \multicolumn{4}{|l|}{ Panel A } \\
\hline$\overline{\text { Fraction Black House candidates }}$ & $\mathrm{NA}^{1}$ & $\begin{array}{c}-0.347 \\
{[0.179]^{*}}\end{array}$ & $\begin{array}{c}-0.441 \\
{[0.226]^{\star}}\end{array}$ \\
\hline Fraction Black Representatives & $\begin{array}{c}-0.079 \\
{[0.176]}\end{array}$ & $\begin{array}{c}-0.145 \\
{[0.142]}\end{array}$ & $\begin{array}{c}-0.363 \\
{[0.206]^{\star}}\end{array}$ \\
\hline Fraction Democratic Representatives & $\begin{array}{r}-4.074 \\
{[2.014]^{\star \star}}\end{array}$ & $\begin{array}{c}-1.797 \\
{[1.332]}\end{array}$ & $\begin{array}{c}-1.524 \\
{[1.131]}\end{array}$ \\
\hline Average Leadership Conference on Civil Rights Score & $\begin{array}{c}-2.514 \\
{[1.350]^{*}}\end{array}$ & $\begin{array}{c}-1.976 \\
{[1.028]^{*}}\end{array}$ & $\begin{array}{c}-1.596 \\
{[0.909]^{\star}}\end{array}$ \\
\hline Average Agreement with Congressional Black Caucus & $\begin{array}{c}-1.281 \\
{[0.675]^{\star}}\end{array}$ & $\begin{array}{c}-1.131 \\
{[0.675]^{*}}\end{array}$ & $\begin{array}{c}-0.882 \\
{[0.535]}\end{array}$ \\
\hline \multicolumn{4}{|l|}{ Panel B } \\
\hline Fraction of districts that have percent Black between 0 and 10 & $\begin{array}{r}1.716 \\
{[0.730]^{\star \star}}\end{array}$ & $\begin{array}{r}1.495 \\
{[0.607]^{\star \star}}\end{array}$ & $\begin{array}{r}1.637 \\
{[0.524]^{\star \star \star}}\end{array}$ \\
\hline Standard deviation of district percent Black & $\begin{array}{l}\quad-1.48 \\
{[3.725]} \\
N=68\end{array}$ & $\begin{array}{l}-2.238 \\
{[9.886]} \\
N=80\end{array}$ & $\begin{array}{l}-0.694 \\
{[0.622]} \\
N=77\end{array}$ \\
\hline
\end{tabular}

Notes: Robust standard errors in brackets. All specifications control for percent Black and length of track.

Sample size $=121$ except where noted. $* * *$ denotes significance at the 1 percent level, ** at the 5 percent level and $*$ at the 10 percent level.

1 Fraction Black House candidates not available for the 1970’s. 
Table VI: Two Stage Least Squares Estimates of the Impact of Segregation on Individual Political Behaviors and Attitudes (Each cell represents the coefficient on the dissimilarity index from a different regression.)

\begin{tabular}{|c|c|c|c|c|c|c|}
\hline 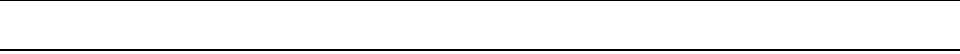 & \multicolumn{3}{|c|}{ Non-Blacks } & \multicolumn{3}{|l|}{ Blacks } \\
\hline & 1970s & 1980s & 1990s & 1970s & 1980s & 1990s \\
\hline \multicolumn{7}{|l|}{ Outcome } \\
\hline \multicolumn{7}{|l|}{ Political Behaviors } \\
\hline Voted in most recent election $^{1}$ & $\begin{array}{l}-0.889 \\
{[0.782]}\end{array}$ & $\begin{array}{l}0.196 \\
{[0.206]}\end{array}$ & $\begin{array}{l}-0.049 \\
{[0.135]}\end{array}$ & $\begin{array}{r}2.826 \\
{[1.436]^{\star}}\end{array}$ & $\begin{array}{l}0.741 \\
{[0.648]}\end{array}$ & $\begin{array}{l}-0.997 \\
{[0.646]}\end{array}$ \\
\hline \multicolumn{7}{|l|}{ Attitudes toward Race } \\
\hline Black/White Thermometer (0 to 100 ) & $\begin{array}{r}14.207 \\
{[25.441]}\end{array}$ & $\begin{array}{r}-10.56 \\
{[5.289]^{\star *}}\end{array}$ & $\begin{array}{r}-24.25 \\
{[9.263]^{\star \star *}}\end{array}$ & & $\begin{array}{r}16.827 \\
{[37.733]}\end{array}$ & $\begin{array}{r}-13.477 \\
{[16.480]}\end{array}$ \\
\hline $\begin{array}{l}\text { Belief that government should aid Blacks (1) through } \\
\text { Blacks should help themselves (7) }\end{array}$ & $\begin{array}{r}2.171 \\
{[3.244]}\end{array}$ & $\begin{array}{r}1.618 \\
{[0.891]^{*}}\end{array}$ & $\begin{array}{r}2.055 \\
{[0.889]^{\star \star}}\end{array}$ & & $\begin{array}{l}-2.36 \\
{[2.892]}\end{array}$ & $\begin{array}{l}0.248 \\
{[2.374]}\end{array}$ \\
\hline \multicolumn{7}{|l|}{ Political Attitudes } \\
\hline $\begin{array}{l}\text { Identification as extremely liberal (1) through extremely } \\
\text { conservative (7) }\end{array}$ & $\begin{array}{r}3.33 \\
{[2.540]}\end{array}$ & $\begin{array}{r}2.134 \\
{[1.151]^{*}}\end{array}$ & $\begin{array}{r}2.832 \\
{[1.102]^{\star \star}} \\
\end{array}$ & & $\begin{array}{l}-2.138 \\
{[1.638]}\end{array}$ & $\begin{array}{l}-1.184 \\
{[2.547]}\end{array}$ \\
\hline $\begin{array}{l}\text { Identification as strong Democrat (1) through strong } \\
\text { Republican }(7)^{2}\end{array}$ & $\begin{array}{r}9.74 \\
{[4.985]^{*}}\end{array}$ & $\begin{array}{l}0.833 \\
{[1.032]}\end{array}$ & $\begin{array}{r}2.216 \\
{[1.242]^{\star}}\end{array}$ & $\begin{array}{l}-0.871 \\
{[0.677]}\end{array}$ & $\begin{array}{l}1.309 \\
{[2.070]}\end{array}$ & $\begin{array}{l}0.265 \\
{[1.878]}\end{array}$ \\
\hline $\begin{array}{l}\text { Voted for the Democrat in most recent Congressional } \\
\text { election }\end{array}$ & $\begin{array}{r}-4.7 \\
{[2.781]^{\star}}\end{array}$ & $\begin{array}{l}-0.417 \\
{[0.616]}\end{array}$ & $\begin{array}{l}-1.015 \\
{[0.587]^{*}}\end{array}$ & & $\begin{array}{l}-0.638 \\
{[0.886]}\end{array}$ & $\begin{array}{l}0.433 \\
{[0.307]}\end{array}$ \\
\hline
\end{tabular}

Notes: Robust standard errors clustered at the congressional district level (or the MSA level for NSBA specifications) in brackets. All specifications contro for length of track. ***denotes significance at the 1 percent level, ** at the 5 percent level and * at the 10 percent level. The data source is the National Election Survey except for the Black 1970s column which comes from the 1979-1980 wave of the National Survey of Black Americans.

1 The National Survey of Black Americans asks whether the respondent voted in the most recent presidential election.

2 The National Survey of Black Americans’ outcome is a non-Democrat indicator. 
Table VII: Two Stage Least Squares Estimates of the Impact of Segregation on non-Black Individual Political Behaviors and Attitudes, Selection vs Environment

(Each cell represents the coefficient on the dissimilarity index from a different regression.)

\begin{tabular}{|c|c|c|c|c|c|c|}
\hline & \multicolumn{3}{|c|}{ Selection } & \multicolumn{3}{|c|}{ Contact } \\
\hline & \multicolumn{3}{|c|}{$\begin{array}{l}\text { Moved to community within past two years, } \\
\text { over age } 30\end{array}$} & \multicolumn{3}{|c|}{30 and under } \\
\hline & $1970 \mathrm{~s}$ & $1980 \mathrm{~s}$ & 1990s & $1970 \mathrm{~s}$ & $1980 \mathrm{~s}$ & $1990 \mathrm{~s}$ \\
\hline \multicolumn{7}{|l|}{ Outcome } \\
\hline \multicolumn{7}{|l|}{ Attitudes toward Race } \\
\hline Black/White Thermometer (0 to 100) & $\begin{array}{r}9.592 \\
{[154.625]} \\
{[N=147]} \\
\end{array}$ & $\begin{array}{r}-24.509 \\
{[23.165]} \\
{[N=237]}\end{array}$ & $\begin{array}{r}-48.631 \\
{[22.352]^{\star \star}} \\
{[\mathrm{N}=245]}\end{array}$ & $\begin{array}{r}40.23 \\
{[36.254]} \\
{[\mathrm{N}=731]}\end{array}$ & $\begin{array}{r}-19.034 \\
{[13.187]} \\
{[\mathrm{N}=853]}\end{array}$ & $\begin{array}{r}-46.947 \\
{[14.313]^{\star \star *}} \\
{[\mathrm{~N}=498]}\end{array}$ \\
\hline $\begin{array}{l}\text { Belief that government should aid Blacks (1) } \\
\text { through Blacks should help themselves (7) }\end{array}$ & $\begin{array}{r}39.427 \\
{[41.765]} \\
{[N=195]}\end{array}$ & $\begin{array}{l}3.561 \\
{[2.799]} \\
{[N=246]}\end{array}$ & $\begin{array}{r}5.731 \\
{[2.097]^{\star \star \star}} \\
{[\mathrm{N}=227]}\end{array}$ & $\begin{array}{l}-1.396 \\
{[3.027]} \\
{[N=903]}\end{array}$ & $\begin{array}{l}1.687 \\
{[1.322]} \\
{[N=825]}\end{array}$ & $\begin{array}{l}2.224 \\
{[1.446]} \\
{[N=463]}\end{array}$ \\
\hline \multicolumn{7}{|l|}{ Political Attitudes } \\
\hline $\begin{array}{l}\text { Identification as extremely liberal (1) through } \\
\text { extremely conservative (7) }\end{array}$ & $\begin{array}{r}5.814 \\
{[14.065]} \\
{[N=181]}\end{array}$ & $\begin{array}{l}5.744 \\
{[4.821]} \\
{[N=220]}\end{array}$ & $\begin{array}{r}7.386 \\
{[3.099]^{\star *}} \\
{[N=202]}\end{array}$ & $\begin{array}{l}-0.238 \\
{[2.493]} \\
{[N=783]}\end{array}$ & $\begin{array}{l}2.524 \\
{[2.042]} \\
{[N=693]}\end{array}$ & $\begin{array}{l}2.629 \\
{[1.783]} \\
{[N=397]}\end{array}$ \\
\hline $\begin{array}{l}\text { Identification as strong Democrat (1) through } \\
\text { strong Republican (7) }\end{array}$ & $\begin{array}{r}22.253 \\
{[20.096]} \\
{[N=227]}\end{array}$ & $\begin{array}{l}5.115 \\
{[3.949]} \\
{[N=263]}\end{array}$ & $\begin{array}{r}6.009 \\
{[2.347]^{\star *}} \\
{[\mathrm{~N}=267]}\end{array}$ & $\begin{array}{l}\quad 4.914 \\
{[3.776]} \\
{[N=1022]}\end{array}$ & $\begin{array}{l}-0.004 \\
{[1.821]} \\
{[\mathrm{N}=898]}\end{array}$ & $\begin{array}{l}1.364 \\
{[1.888]} \\
{[N=540]}\end{array}$ \\
\hline $\begin{array}{l}\text { Voted for the Democrat in most recent } \\
\text { Congressional election }\end{array}$ & $\begin{array}{r}-9.944 \\
{[12.335]} \\
{[\mathrm{N}=98]}\end{array}$ & $\begin{array}{c}-3.631 \\
{[3.609]} \\
{[N=124]}\end{array}$ & $\begin{array}{c}-2.358 \\
{[1.450]} \\
{[\mathrm{N}=127]}\end{array}$ & $\begin{array}{c}-3.998 \\
{[2.746]} \\
{[N=414]}\end{array}$ & $\begin{array}{c}-1.824 \\
{[1.607]} \\
{[N=297]}\end{array}$ & $\begin{array}{c}-0.308 \\
{[0.694]} \\
{[N=221]}\end{array}$ \\
\hline
\end{tabular}

Notes: Robust standard errors clustered at the congressional district level in brackets. All specifications control for length of track.

***denotes significance at the 1 percent level, ** at the 5 percent level and * at the 10 percent level. 
Appendix Table I: MSAs included in the 2SLS Analysis

\begin{tabular}{|c|c|c|}
\hline Akron, $\mathrm{OH}$ & Iowa City, IA & Pueblo, CO \\
\hline Albany-Schenectady-Troy, NY & Jackson, MI & Reading, PA \\
\hline Altoona, PA & Jamestown-Dunkirk, NY & Redding, CA \\
\hline Anaheim-Santa Ana, CA & Janesville-Beloit, WI & Reno, NV \\
\hline Ann Arbor, MI & Johnstown, PA & Riverside-San Bernardino, CA \\
\hline Atlantic City, NJ & Joliet, IL & Rochester, NY \\
\hline Aurora-Elgin, IL & Kalamazoo, MI & Rockford, IL \\
\hline Battle Creek, MI & Kankakee, IL & Saginaw-Bay City-Midland, MI \\
\hline Beaver, PA & Lancaster, PA & Salem-Gloucester, MA \\
\hline Benton Harbor, MI & Lansing-East Lansing, MI & Salem, OR \\
\hline Binghamton, NY & Las Cruces, NM & Salinas-Seaside-Monterey, CA \\
\hline Bloomington, IN & Lawrence, MA & San Francisco, CA \\
\hline Boise City, ID & Lawton, OK & Santa Barbara-Santa Maria- \\
\hline Boulder-Longmont, CO & Lima, $\mathrm{OH}$ & Lompoc, CA \\
\hline Bridgeport-Milford, CT & Lorain-Elyria, OH & Santa Cruz, CA \\
\hline Brockton, MA & Los Angeles-Long Beach, CA & Santa Rosa-Petaluma, CA \\
\hline Buffalo, NY & Lowell, MA-NH & Scranton, PA \\
\hline Burlington, VT & Manchester, NH & Seattle, WA \\
\hline Canton, $\mathrm{OH}$ & Mansfield, OH & Spokane, WA \\
\hline Champaign-Urbana-Rantoul, IL & Merced, CA & Springfield, IL \\
\hline Chico, CA & Middletown, CT & Springfield, MA \\
\hline Cincinnati, OH-KY-IN & Minneapolis-St. Paul, MN-WI & State College, PA \\
\hline Colorado Springs, CO & Muskegon, MI & Steubenville-Weirton, OH-WV \\
\hline Danbury, CT & Newark, NJ & Stockton, CA \\
\hline Dayton-Springfield, $\mathrm{OH}$ & New Bedford, MA & Syracuse, NY \\
\hline Decatur, IL & New Haven-Meriden, CT & Toledo, $\mathrm{OH}$ \\
\hline Des Moines, IA & New London-Norwich, CT-RI & Trenton, NJ \\
\hline Detroit, MI & Niagara, NY & Tucson, AZ \\
\hline Duluth, MN-WI & Norwalk, CT & Utica-Rome, NY \\
\hline Elmira, NY & Oakland, CA & Vancouver, WA \\
\hline Erie, PA & Oklahoma City, OK & Vineland-Millville-Bridgeton, NJ \\
\hline Eugene-Springfield, OR & Olympia, WA & Visalia-Tulare-Porterville, CA \\
\hline Fall River, MA-RI & Omaha, NE-IA & Waterbury, CT \\
\hline Fitchburg-Leominster, MA & Peoria, IL & Williamsport, PA \\
\hline Flint, MI & Philadelphia, PA-NJ & Worcester, MA \\
\hline Fort Collins-Loveland, CO & Phoenix, AZ & Yakima, W A \\
\hline Glens Falls, NY & Pittsfield, MA & York, PA \\
\hline Grand Forks, ND-MN & Portland, ME & Youngstown-Warren, OH \\
\hline Grand Rapids, MI & Portland, OR & Yuba City, CA \\
\hline Hamilton-Middletown, $\mathrm{OH}$ & Portsmouth-Dover-Rochester, & \\
\hline Harrisburg-Lebanon-Carlisle, PA & NH-ME & \\
\hline Hartford, CT & Poughkeepsie, NY & \\
\hline
\end{tabular}


Appendix Table II: Two Stage Least Squares Estimates of the Impact of Segregation on Black Political Efficacy Across Decades, Expanded Specification

(Each cell represents the coefficient on the dissimilarity index from a different regression.)

\begin{tabular}{|l|c|c|c|}
\hline & $1970 \mathrm{~s}$ & $1980 \mathrm{~s}$ & $1990 \mathrm{~s}$ \\
\hline Panel A & & & \\
\hline Fraction Black House candidates & $\mathrm{NA}^{1}$ & -0.588 & -0.359 \\
& {$[0.466]$} & {$[0.232]$} \\
\hline Fraction Black Representatives & -0.003 & -0.237 & -0.354 \\
& {$[0.193]$} & {$[0.314]$} & {$[0.217]$} \\
\hline Fraction Democratic Representatives & -3.961 & -4.059 & -0.655 \\
& {$[2.452]$} & {$[3.454]$} & {$[0.917]$} \\
\hline Average Leadership Conference on Civil Rights Score & -3.134 & -3.989 & -0.943 \\
& {$[1.875]^{*}$} & {$[2.971]$} & {$[0.690]$} \\
\hline Average Agreement with Congressional Black Caucus & -1.538 & -2.262 & -0.448 \\
& {$[0.897]^{*}$} & {$[1.837]$} & {$[0.398]$} \\
\hline & & & \\
\hline Panel B & & & \\
\hline Fraction of districts that have percent Black between 0 and 10 & 2.158 & 2.806 & 1.607 \\
& {$[1.123]^{*}$} & {$[1.802]$} & {$[0.493]^{\star \star \star}$} \\
\hline Standard deviation of district percent Black & -0.775 & 4.721 & -0.538 \\
& {$[1.310]$} & {$[43.192]$} & {$[0.469]$} \\
\hline
\end{tabular}

Notes: Robust standard errors in brackets. All specifications control for percent Black, length of track, percent

of population under 18, percent poverty, percent employed and percent with a high school diploma. Sample

size $=121$ except where noted. ${ }^{* * *}$ denotes significance at the 1 percent level, ${ }^{* *}$ at the 5 percent level and $*$ at

the 10 percent level.

1 Fraction Black House candidates not available for the 1970’s. 
Appendix Table III: Means for District Characteristics Across decades

(Standard deviations in parentheses.)

\begin{tabular}{|l|c|c|c|}
\hline & $1970 \mathrm{~s}$ & $1980 \mathrm{~s}$ & $1990 \mathrm{~s}$ \\
\hline$\underline{\text { Panel A }}$ & & & \\
\hline$\underline{\text { Outcome }}$ & & & \\
\hline Fraction of districts with percent Black ... & & & \\
\hline $0-10 \%$ & .95 & .95 & .91 \\
$\mathrm{~N}$ & $(.18)$ & $(.17)$ & $(.20)$ \\
\hline & 121 & 121 & 121 \\
\hline Panel B & & & \\
\hline Outcome & & & \\
\hline Standard deviation of percent Black & & & \\
\hline $\mathrm{N}$ & $(.03)$ & .03 & .04 \\
& 68 & 80 & 77 \\
\hline
\end{tabular}


Appendix Table IV: First Stage for Political Attitudes

\begin{tabular}{|l|l|l|l|l|l|l|l|}
\hline \multicolumn{9}{|l|}{ National Election Studies } & National Survey of Black Americans \\
\hline & Non-Black & \multicolumn{2}{l|}{ Black } & \\
\hline & $1970 \mathrm{~s}$ & $1980 \mathrm{~s}$ & $1990 \mathrm{~s}$ & $1970 \mathrm{~s}$ & $1980 \mathrm{~s}$ & $1990 \mathrm{~s}$ & $1979-1980$ \\
\hline Railroad Division Index & $.184^{* *}$ & $.491^{* * *}$ & $.529^{* * *}$ & .126 & $.384^{* * *}$ & $.511^{* * *}$ & $.260^{* * *}$ \\
& $(.074)$ & $(.112)$ & $(.112)$ & $(.085)$ & $(.184)$ & $(.169)$ & $(.035)$ \\
\hline $\mathrm{N}$ & 3721 & 3832 & 3241 & 248 & 217 & 202 & 379 \\
\hline
\end{tabular}

Notes: Robust standard errors clustered at the congressional district level (or the MSA level for NSBA specifications) in brackets. All specifications control for length of track. 
Appendix Table V: Means for Individual Political Behaviors and Attitudes

(Standard errors in parentheses. Sample size in brackets.)

\begin{tabular}{|c|c|c|c|c|c|c|}
\hline & \multicolumn{3}{|c|}{ Non-Blacks } & \multicolumn{3}{|c|}{ Blacks } \\
\hline & 1970s & 1980s & 1990s & 1970s & 1980s & 1990s \\
\hline \multicolumn{7}{|l|}{ Focal Independent Variable } \\
\hline Dissimilarity Index & $\begin{array}{l}.75 \\
(.08) \\
{[3721]}\end{array}$ & $\begin{array}{l}.646 \\
(.111) \\
{[3832]}\end{array}$ & $\begin{array}{l}.592 \\
(.131) \\
{[3241]}\end{array}$ & $\begin{array}{l}.802^{1} \\
(.094) \\
{[327]}\end{array}$ & $\begin{array}{l}.716 \\
(.097) \\
{[217]}\end{array}$ & $\begin{array}{l}.67 \\
(.133) \\
{[202]}\end{array}$ \\
\hline \multicolumn{7}{|l|}{ Outcomes } \\
\hline Voted in most recent election $^{1}$ & $\begin{array}{l}.701 \\
(.458) \\
{[3413]}\end{array}$ & $\begin{array}{l}.651 \\
(.477) \\
{[3668]}\end{array}$ & $\begin{array}{l}.732 \\
(.443) \\
{[3049]}\end{array}$ & & $\begin{array}{l}.611 \\
(.489) \\
{[203]}\end{array}$ & $\begin{array}{c}.7 \\
(.461) \\
{[165]}\end{array}$ \\
\hline Black/White Thermometer (0 to 100) & $\begin{array}{l}61.3 \\
(18.2) \\
{[2533]}\end{array}$ & $\begin{array}{l}63.6 \\
(20.29) \\
{[3499]}\end{array}$ & $\begin{array}{l}63.45 \\
(18.11) \\
{[2931]}\end{array}$ & & $\begin{array}{l}66.9 \\
(22.3) \\
{[102]}\end{array}$ & $\begin{array}{l}71.7 \\
(19.3) \\
{[161]}\end{array}$ \\
\hline $\begin{array}{l}\text { Belief that government should aid Blacks (1) through Blacks should help } \\
\text { themselves (7) }\end{array}$ & $\begin{array}{l}4.39 \\
(1.78) \\
{[3130]}\end{array}$ & $\begin{array}{l}4.4 \\
(1.57) \\
{[3429]}\end{array}$ & $\begin{array}{l}4.73 \\
(1.61) \\
{[2724]}\end{array}$ & & $\begin{array}{l}3.28 \\
(1.82) \\
{[197]}\end{array}$ & $\begin{array}{c}3.79 \\
(1.99) \\
{[180]}\end{array}$ \\
\hline Identification as extremely liberal (1) through extremely conservative (7) & $\begin{array}{l}4.16 \\
(1.3) \\
{[2609]}\end{array}$ & $\begin{array}{l}4.25 \\
(1.31) \\
{[2881]}\end{array}$ & $\begin{array}{l}4.28 \\
(1.38) \\
{[2391]}\end{array}$ & & $\begin{array}{l}3.78 \\
(1.41) \\
{[148]}\end{array}$ & $\begin{array}{c}3.84 \\
(1.5) \\
{[138]}\end{array}$ \\
\hline Identification as strong Democrat (1) through strong Republican $(7)^{2}$ & $\begin{array}{l}3.8 \\
(1.92) \\
{[3642]}\end{array}$ & $\begin{array}{l}3.96 \\
(2.06) \\
{[3767]}\end{array}$ & $\begin{array}{l}3.86 \\
(2.05) \\
{[3209]}\end{array}$ & $\begin{array}{c}.34^{1} \\
(.47) \\
{[321]}\end{array}$ & $\begin{array}{l}2.28 \\
(1.4) \\
{[214]}\end{array}$ & $\begin{array}{c}2.18 \\
(1.35) \\
{[200]}\end{array}$ \\
\hline Voted for the Democrat in most recent congressional election & $\begin{array}{c}.526 \\
(.499) \\
{[2011]}\end{array}$ & $\begin{array}{l}.554 \\
(.497) \\
{[2047]}\end{array}$ & $\begin{array}{l}.511 \\
(.5) \\
{[1901]}\end{array}$ & & $\begin{array}{c}.878 \\
(.329) \\
{[98]}\end{array}$ & $\begin{array}{c}.877 \\
(.331) \\
{[81]}\end{array}$ \\
\hline
\end{tabular}

The data source is the National Election Survey except for the Black 1970s column which comes from the 1979-1980 wave of the National Survey of Black Americans.

1 The National Survey of Black Americans asks whether the respondent voted in the most recent presidential election.

2 The National Survey of Black Americans' outcome is a non-Democrat indicator. 